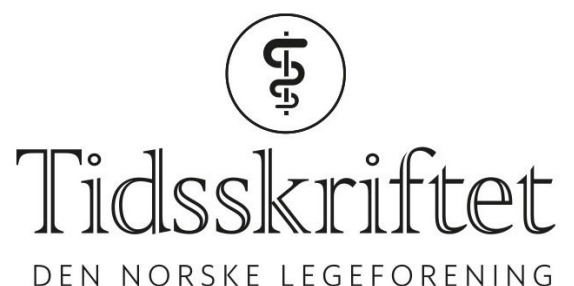

DEN NORSKE LEGEFORENING

\title{
Rus og nevrologi: A Dream Within a Dream
}

MEDISIN OG KUNST

\section{MIA TUFT}

E-post: miatuft@neuropsychology.no Mia Tuft er nevropsykolog og jobber til daglig med sjeldne epilepsirelaterte diagnoser ved Oslo universitetssykehus.

Forfatter har fylt ut ICMJE-skjemaet og oppgir ingen interessekonflikter.

Forfatteren Edgar Allan Poe er en av mange kunstnere som beskriver hvordan det føles å leve med store, ufrivillige bevissthetsendringer. Skyldes hans store opp- og nedturer i livet en nevrologisk tilstand, eller kan rus og depressive tanker forklare de store svingningene?

Edgar Allan Poes (1809-49) liv og helsetilstand var utenom det vanlige og har kanskje preget hans underfundige måte å formulere seg på. Tankene i det kjente diktet A Dream Within a Dream (1849) kan ses som et bakteppe for Edgars siste år.

\section{Spekulasjoner rundt dødsårsak}

Det ble sagt at den dagen han døde, bare 40 år gammel, hadde han drukket bare ett glass med alkohol på en bar. Like etter ble han funnet bevisstløs på gaten (1). Han ble brakt til sykehuset. Under transport dit var han delvis bevisst og klaget over hodepine. Så forsvant han inn i hallusinasjoner og senere bevisstløshet eller koma. Tre dager senere døde han.

Enkelte mener at han døde av ikke-konvulsiv status epilepticus (1). Andre mener at dødsårsaken var encefalitt, delirium tremens, pneumoni (2), rabies (3), syfilis (4) hodetraume (5) eller diabeteskoma (6).

Noen få måneder før han døde hadde han publisert et av sine mest kjente dikt, A Dream Within a Dream, som presenteres her som en komprimert del av hans litterære karriere. Diktet illustrerer hvordan Edgar mistet kontroll over seg selv, sin hukommelse og sin bevissthet. Sannsynligvis dveler han også ved hvilke muligheter han har mistet ved å være fraværende og ruset.

\section{A Dream Within a Dream \\ Take this kiss upon the brow! And, in parting from you now, Thus much let me avow- You are not wrong, who deem That my days have been a dream;}


Yet if hope has flown away

In a night, or in a day,

In a vision, or in none,

Is it therefore the less gone?

All that we see or seem

Is but a dream within a dream.

I stand amid the roar

Of a surf-tormented shore,

And I hold within my hand

Grains of the golden sand -

How few! yet how they creep

Through my fingers to the deep,

While I weep - while I weep!

O God! Can I not grasp

Them with a tighter clasp?

O God! can I not save

One from the pitiless wave?

Is all that we see or seem

But a dream within a dream?

Edgar Allen Poe

Første gang publisert 31. mars 1849 (7)

\section{Å leve i en drøm}

Den åpenbare tolkningen av diktet er at han reflekterer over sitt kjærlighetsliv, der han forsøker å se seg tilbake for å gjenoppleve tidligere hendelser. Minnene om kjærligheten er svært vage. Til sin fortvilelse husker han ikke lenger det som er verdifullt for ham. Årsakene til at minnene glipper, kan være mange. Kanskje han ruset seg så mye at det var vanskelig å trekke ut de faktiske hendelsene? Var det derfor minnene var vage eller ikke-eksisterende? Kanskje var han på vei inn i en alkoholindusert tilstand som Wernickes encefalopati i sitt siste leveår?

Alkoholinntaket hans kan likevel ikke fullt ut forklare hans tilstand, blant annet fordi han var velformulert og reflektert inntil det siste. Korsakoffs psykose er ingen plausibel forklaring, for hans tilstedeværelse gikk i svingninger og han tok til seg ny kunnskap.

Edgar Allan Poe beskriver i sin litteratur lag på lag av drømmer og lag på lag av usikkerhet rundt egen bevissthet og hukommelse. Rus kombinert med depresjon, selvdestruktiv atferd og anfall med ukjent årsak bidro sannsynligvis sammen til den gradvise forverringen av hans helsetilstand. Med diktet fanger han opp noe allmennmenneskelig: følelsen av livet som flyktig og hukommelsen som upålitelig. Han klarte paradoksalt nok, i rusen, å beskrive noe som gjelder oss alle.

\footnotetext{
LITTERATUR:

1. Bazil CW. Seizures in the life and works of Edgar Allan Poe. Arch Neurol 1999; 56: 740 -3. [PubMed][CrossRef]

2. Scarlett C. A tale of ratiocination: the death and burial of Edgar Allan Poe. Md Hist Mag 1978; 73:36o 74. [PubMed]

3. Benitez RMA. A 39-year-old man with mental status change. Md Med J 1996; 45: 765 - 9. [PubMed]

4. Gordon AG. The death of Edgar Allan Poe-a case of syphilis? Md Med J 1997; 46: 289 - 9o. [PubMed]

5. Patterson R. Once upon a midnight dreary: the life and addictions of Edgar Allan Poe. CMAJ 1992; 147: 1246 - 8. [PubMed]
} 
6. Hill JS. The diabetic Mr Poe. Poe Newsletter 1968; 1:30 - 1.

7. Sova DB. Edgar Allan Poe: A to Z. New York, NY: Checkmark Books, 2001: 73.

Publisert: 10. desember 2018. Tidsskr Nor Legeforen. DOI: 10.4045/tidsskr.18.o616

Mottatt 8.8.2018, første revisjon innsendt 19.10.2018, godkjent 5.11.2018.

(C) Tidsskrift for Den norske legeforening 2020. Lastet ned fra tidsskriftet.no 